\title{
ABOUT THE POSSIBILITY OF IRON ABSORPTION BY FISHES AND ITS PATHOLOGICAL ACTION
}

\author{
by J. A. Machado Cruz.
}

\section{1. - Introduction.}

In a previous paper, in which I reported about the experimental results of the action on fishes of iron salts added to the water medium, I stated that iron had often been found in the epithelium and in the connective tissue of the digestive tract, as well as in the cells and in the vessels of other organs, such as, for example, the liver, the kidneys, etc... But it had never been traced in appreciable quantities within the cells of the gill epithelium.

This led me to think that, as far as fishes are concerned, iron salts may determine not only the generally accepted external and mechanical branchial action, as demonstrated by CARPENTER [1924, $1925,1927,1930]$, the cytological and histological branchial lesions, excellently demonstrated by KuHN and KoEcKe [1956], and destructive lesions of the gastric and intestinal mucosa Cruz [1969], but that they may also have internal pathological action.

Moreover, I kept in mind that iron was absorbed principally by the digestive tract, since no evidence of absorption by the gills could be found.

In my previous experiments I obtained in the animals used for the purpose a mixture of external and internal lesions caused by iron. As, at least in most cases, the external lesions predominated over the internal ones and they must have had a more important influence on the «mortis causa».

Now, it would be interesting to study, by means of the same techniques, the lesions in the same organs, but caused separately by the internal and by the external action of iron.

This can be done :

- by injection of iron salts into the digestive tract;

- by injection of iron salts into the circulatory system;

- by putting fishes in water containing iron salts, at the same time eliminating the possibility of the fishes absorbing iron through the digestive tract. 
The third method of approach will lead to satisfactory results, only if the iron is not absorbed, in any appreciable quantities by the gills and by the skin, which $I$ think is the case. At the same time it will be a way to prove or to refute this hypothesis.

In this paper I propose to approach the problem by means of the first method, i.e. by injection of an iron salt into the digestive tract.

\section{2. - Material and Methods.}

Seven fishes, Carassius auratus L., weighting between 12 and $18 \mathrm{~g}$ each, were inoculated in the digestive tract by mouth tubing with a solution of $2 \% \mathrm{SO}_{4} \mathrm{Fe}$ in distilled water, prepared in the moment of inoculation and corresponding to $200 \mathrm{mg}$ of iron by $\mathrm{kg}$ weight of body.

Six other similar fishes were inoculated under the same conditions, but with doses of $150 \mathrm{mg}$ of iron by $\mathrm{kg}$ of weight.

After inoculation each fish was placed and observed in a separate glass aquarium containing 2 litres of water permanently aerated.

When death came, the autopsy was immediately performed and the following organs selected for histological and histochemical examination : the liver, the entire digestive tract, the kidneys, the brain and gills.

All the organs, with the exception of the entire digestive tract, were divided in two pieces, one for preservation in $10 \%$ neutral formalin, the other for Bouin fluid preservation.

From each organ paraffin sections were made, all of them stained with Azan, Weigert-Haematoxylin — Van Gieson, Hotchkiss Mac Manus and Turnbull blue - nuclear red techniques.

Sections in neutral formalin were selected for the Turnbull blue technique, and for the other techniques those preserved in Bouin fluid.

All the sections were observed with the usual high microscopical magnification, and the negative ones in Turnbull staining were always observed with an oil immersion as well.

General microscopical examination was made, and particular attention was paid to the points outlined in Table 1.

\section{3. - The Autopsy Findings.}

In the autopsy no more than gill cianosis, congestion of the branchial vessels, and congestion of the liver and of the digestive tract were found. 


\section{4. - Behaviour during the Experiments.}

The behaviour of the animals used for the experiments was not abso'utely alike.

Generally speaking, they had a short period of excitation at the beginning, and then a comparatively much longer period in a comalike state, with progressively smaller frequency and amplitude of opercular movements.

\section{5. - The Histological Lesions and the Histochemical Findings.}

In Table $1 \mathrm{I}$ show, schematically and individually, the histological alterations, the histochemical iron findings, and the survival time observed in the seven more heavily inoculated fishes.

With regard to the survival time, two groups of individuals may be observed : one having, so to speak, an acute iron intoxication, and the other a sub-acute iron intoxication.

In both cases several lesions are similarly to be seen, the only difference being a question of degree. But, in the group with the so called acute iron intoxication, the destructive gill lesions are particularly accentuated, and the presence of Turnbull positive vascular thrombi in the gills and in the liver is particularly clear and frequent.

Beyond the findings schematically presented in Table 1, I found iron impregnation of the gill cartilage, and iron impregnation of the walls of venous vessels of the intestinal wall and of the liver.

Degeneration of the liver, with lysis of several cells and the breakage of the wall of some vessels, was also observed.

Intracellular iron in the liver and in the kidney tube cells was found in the form of fine granules.

Iron in the brain was not found.

Some rare Turnbull positive cells, apparently in the process of elimination, were also observed in the gill epithelium.

In a less accentuated degree and with the exception of iron positive thrombi in the blood vessels of the liver, kidneys and gills, the same types of lesions were observed in the individuals inoculated with $150 \mathrm{mg}$ of iron by $\mathrm{kg}$ of weight of body.

\section{6. - Discussion.}

The results of the experiments here mentioned seem to me to demonstrate the principal, histologically and histochemically detectable, pathological actions of iron absorbed in large quantities by the digestive tract of fishes. 


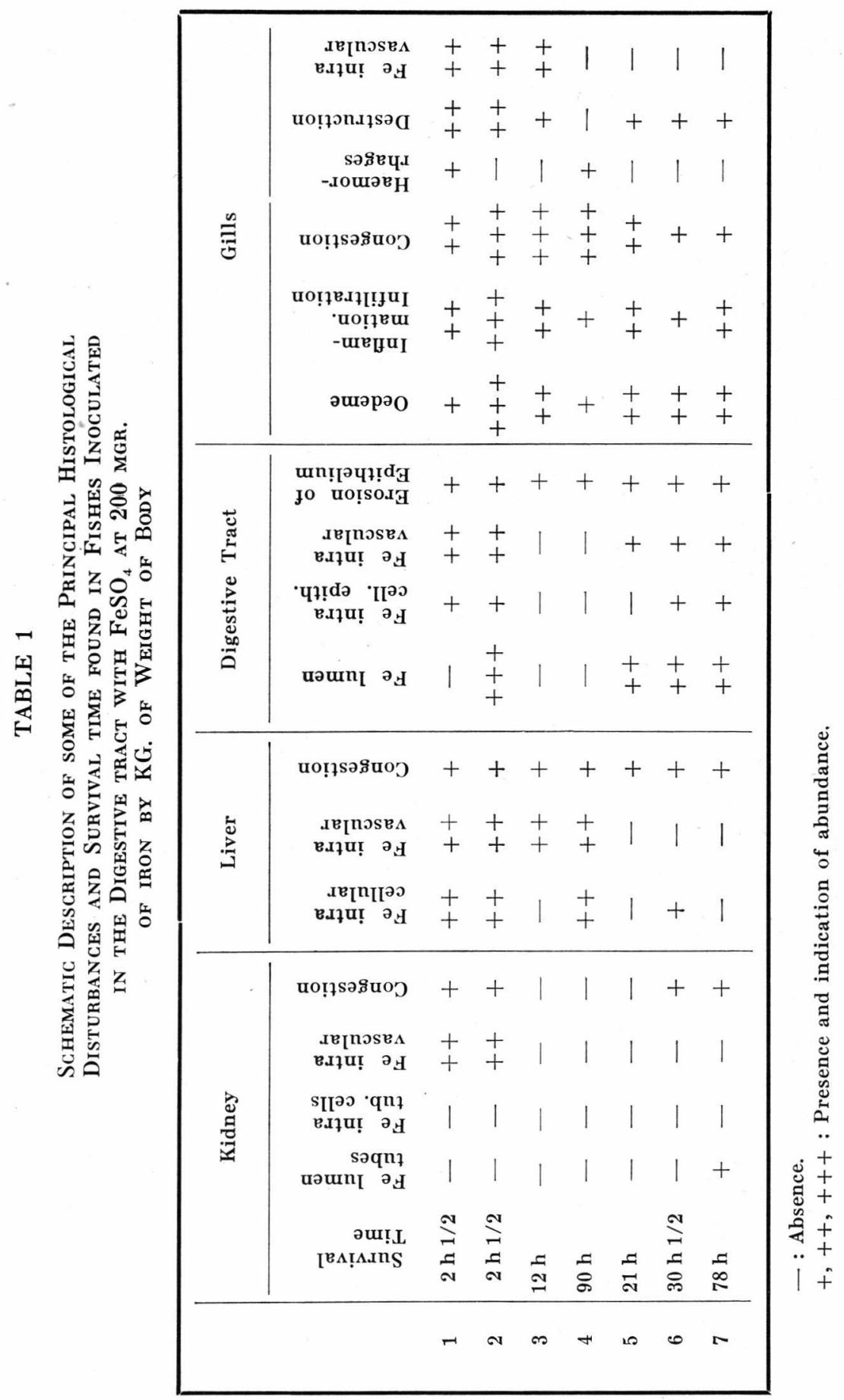




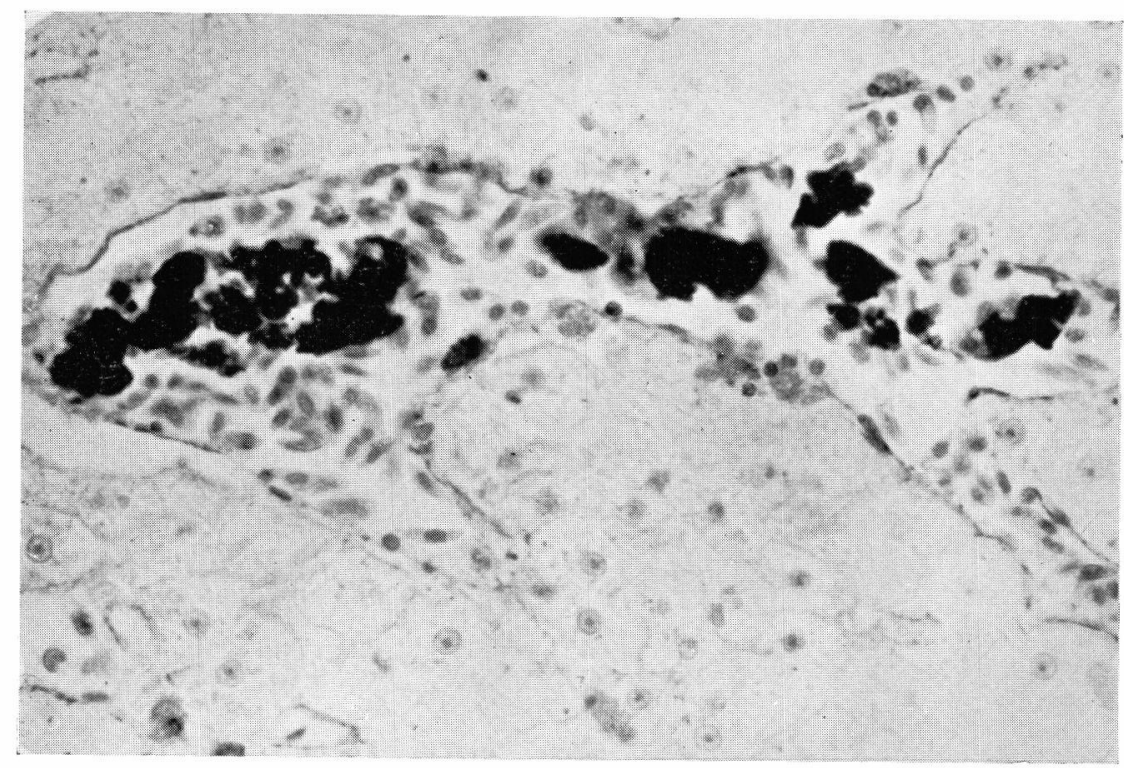

Fig. 1. - Photomicrograph of histological sections of liver with iron positive thrombi in a venous vessel. - Fish $n^{\circ} 3$. Turnbull-nuclear red st. $575 \times$

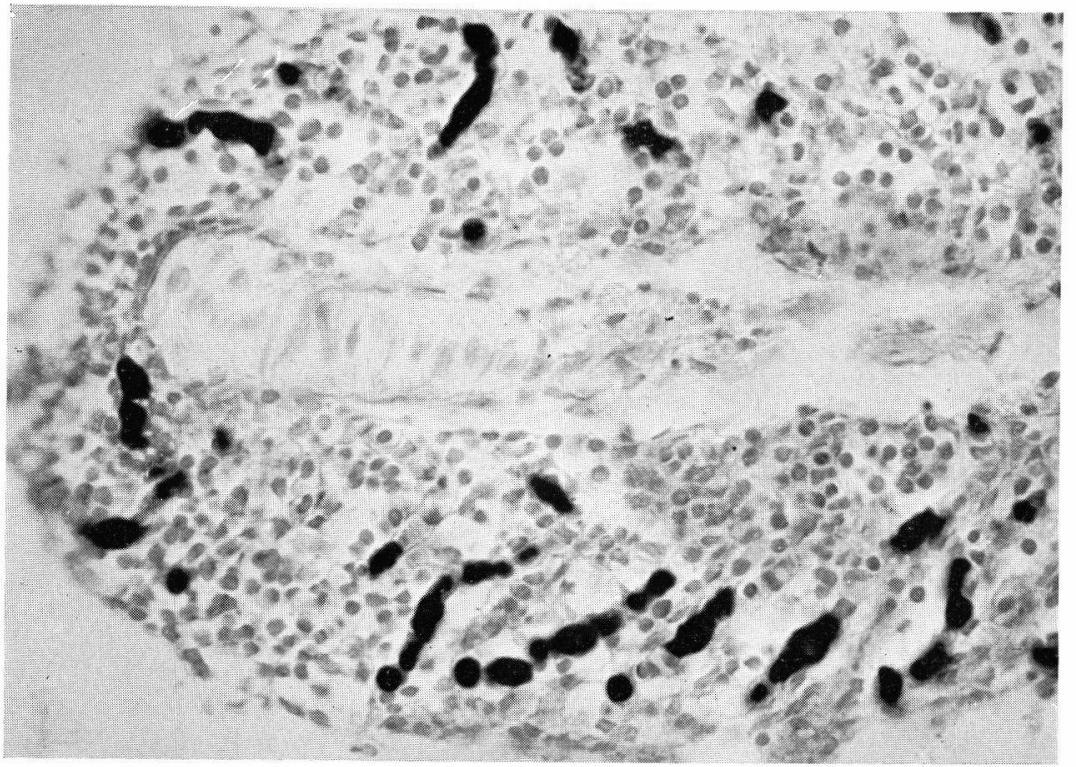

FIG. 2. - Photomicrograph of a histological section of gills. Iron positive thrombi in the capillaries of the respiratory folds and destructive lesions of respiratory epithelium. - Fish $n^{\circ}$ 1. Turnbull-nuclear red st. $575 \mathrm{x}$ 


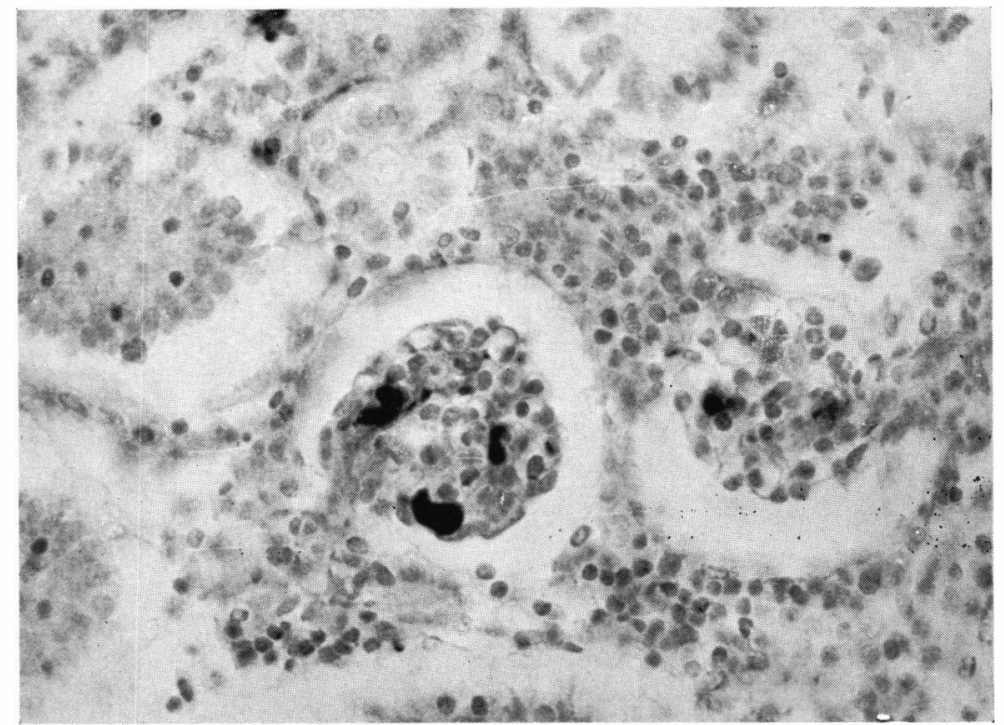

Fig. 3. - Photomicrograph of a histological section of kidney. Iron positive thrombi in the glomerules. - Fish $\mathrm{n}^{\circ} 1$. Turnbull-nuclear red st. $575 \mathrm{x}$

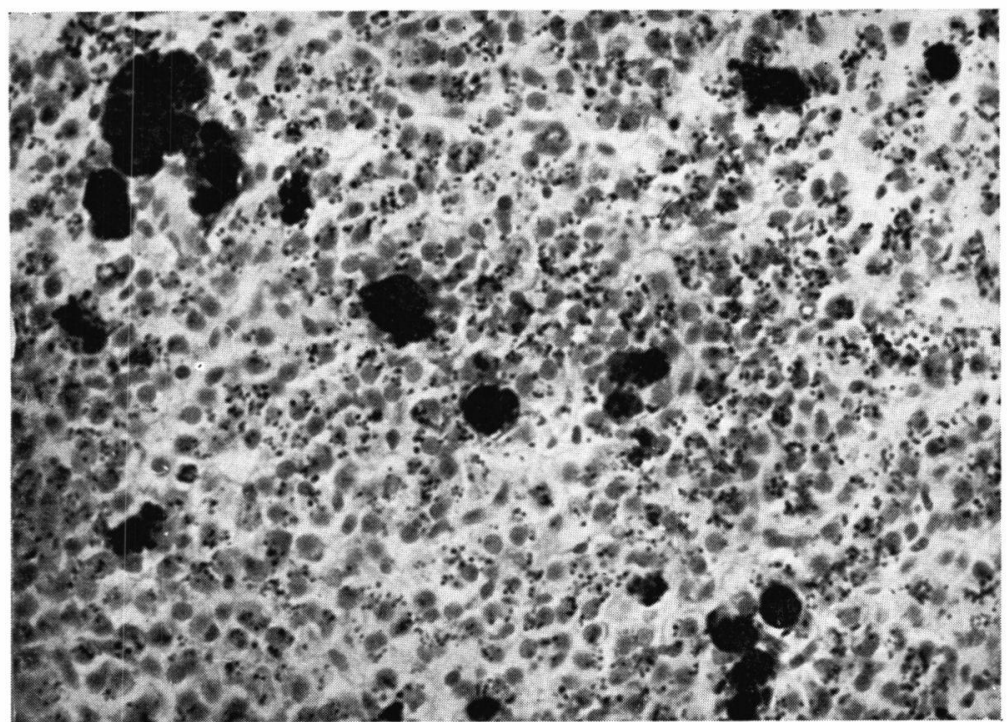

Fig. 4. - Photomicrograph of a histological section of the liver of a fish that lived for 3 hours in a fresh solution of $\mathrm{Fe} \mathrm{SO}_{4}$ in distilled water, with $100 \mathrm{mgr}$ of $\mathrm{Fe}$ per litre. Intracellular iron positive granules and iron positive vessel thrombi are particularly clear. - Turnbull-nuclear red st. $500 \mathrm{x}$ 
As far as I could ascertain in the available literature, iron was thought to have for fishes - exception made for LARoze [1955] and CRuz [1969 - a harmful external action only.

Thus, there is no bibliography offering the possibility of comparing the experimental lesions in fishes obtained by me with corresponding results obtained by others.

But it is quite interesting to compare these experimental lesions in fishes with lesions found in children who died of iron poisoning, and those found in mammals experimentally poisoned by iron salts.

When I consider the total amount of disturbances (excepting, obviously, the branchial ones) found by me, and the total amount of disturbances mentioned in the various cases reported in the available bibliography, I assume that all of them have been found in human beings as well as in mammals used for laboratory experiments.

Some of these disturbances appear almost constantly as, for example, the congestion phenomena, the deposition of iron in the liver cells, the tendency to liver necrosis etc. but some others, however, are not so frequent.

This seems to be the case with regard to iron positive thrombi in blood vessels. In the bibliography to which I had access, these disturbances were found only in the venous vessels of the wall of the digestive tract and of the liver, and in two cases only of ironpoisoned children, studied respectively by SMrTH, Jones and Cochran [1950] and by Swift, Cefalu and Rubell [1952].

In particular, iron positive thrombi were not found in the series of rabbits and dogs used for experiments and studied meticulously and in very interesting detail by ReissmanN and Col. [1955].

In my own experiments, I could very clearly see these thrombi in three cases; and taking into account their frequency in the liver, gills ans kidney glomerules, they seemed to exist in great quantities in the blood-stream.

Moreover, I have found [CRuz, 1969] that such thrombi are fairly frequent in fishes which have lived, for some time, in water containing a large quantity of iron salts.

The thrombic phenomena seem to be much more frequent in fishes than in mammals.

Naturally the question arises : what is the real composition of such iron positive thrombi and what is the chemical form assumed by iron in them and in the plasma.

I could make no experiments in this field.

But I believe it is interesting to recall that, after dialysis experiments on the plasma of the animals used for the purpose, ReissmanN and Col. [1955] concluded that iron was not or only loosely protein 
bound, and they assumed that probably it appeared in a colloidal ferric hydroxide form.

May not, then, these vessel thrombi be, at least partially, colloidal ferric hydroxide compounds?

This is a new question requiring an answer.

\section{7. - Summary and Conclusions.}

1. Iron, when absorbed in large quantities by the digestive tract of fishes, can produce in various organs internal lesions which can be histologically and histochemically detected.

2. These lesions are sufficient to lead to death.

3. Such lesions are very similar to those found either in ironpoisoned human beings or in mammals iron-poisoned for experimental purposes.

4. To the above lesions is added, for fishes a more or less pronounced degeneration of the branchial epithelium.

\section{SUR LES POSSIBHTTES D'ABSORPTION DE FER PAR LES POISSONS ET SON ACTION PATHOLOGIQUE}

1. - Quand il est absorbé en grande quantité par le tube digestif des poissons, le fer peut provoquer, en divers organes, des lésions internes qui peuvent être histologiquement et histochimiquement détectées.

2. - Ces lésions sont suffisantes pour entraîner la mort.

3. - De telles lésions sont très semblables à celles trouvées dans les êtres humains ou les mammifères emprisonnés par le fer.

4. - A ces lésions s'ajoute une dégénération plus ou moins prononcée de l'épithélium branchial.

\section{UBER DIE MOGLICHKEITEN DER ABSORPTION VON EISEN DURCH DIE FISCHE UND DEREN PATHOLOGISCHE WIRKUNG}

1. - Wenn Eisen in grosser Menge über den Verdauungskanal der Fische adsorbiert wird, kann dieses in verschiedenen Organen zu inneren Verletzungen führen welche auf histologischem Wege erkannt werden können.

2. - Diese Läsionen sind so stark, dass sie den Tod verursachen können.

3. - Derartige Läsionen sind äusserst vergleichbar mit denjeninger die bei Eisen vergiftungen von menschlichen Lebewesen und Sängetieren beobachtet wurden.

4. - Diese Läsionen sind von einer mehr oder weniger starken Beeinträchtigung des Kiemenepitheliums begleitet. 


\section{LITERATURE GITED}

Carpenter (K. E.). 1924. - . A study of the fauna of rivers polluted by lead mining in the Aberystwyth district of Cardiganshire. Ann. Appl. Biol., 11 : 1.23.

Carpenter (K. E.). 1925. -- On the biological factors involved in the destruction of river-fisheries by pollution due to lead-mining. Ann. Appl. Biol., 12 : 1-13.

Carpenter (K. E.). 1927. - The lethal action of soluble metallic salts on fishes. Bril. Journ. Biol., 4 : 378-390.

Carpenter (K. E.). 1930. - Further researches on the action of metallic salts on fishes. Journ. Exp. Zool., 56 : 407-422.

Chuz (J. A. M.). 1969. - Iron salts in ichthyopathology - Histological and histochemical experimental contribution. Publ. Inst. Zool. Dr. A. Nobre, $\mathrm{n}^{\circ} 106$.

KUHN (O.) and KOECKe (H.). 1956. - Histologische und cytologische Veränderungen der Fischkieme nach Einwirkung im Wasser enthaltener schädigender Substanzen. $Z$. f. Zellforschung, $43:$ 611-643.

Reissmann (K.) ancl Coll. 1955. -- Acute intestinal iron intoxication I. Iron absorption, serum iron and autopsy findings II. Metabolic, respiratory and circulatory effects of absorbed iron slats. Blood, 10 : 35-51.

Smith (R.), Jones (C.) and Cochran (W.). 1950. - Ferrous sulfate toxicity : Report of a fatal case. New England Journ. Med., 243 : 641-645.

Swift (S.), Cefalu (V.) and Rubell (E.). 1952. - Ferrous sulfate poisoning. Journ. Pediat., $40: 6-10$.

(Faculty of Sciences, ('niversity of Porto - Portugal.) 